\title{
EBI3 wt Allele
}

National Cancer Institute

\section{Source}

National Cancer Institute. EBI3 wt Allele. NCI Thesaurus. Code C117089.

Human EBI3 wild-type allele is located in the vicinity of $19 \mathrm{p} 13.3$ and is approximately $8 \mathrm{~kb}$ in length. This allele, which encodes interleukin-27 subunit beta protein, is involved in the regulation of inflammation, tumorigenesis and angiogenesis. 